\title{
Transatlantic Trade and InVEstment Partnership (TTIP): The Devil in Disguise or a Golden Opportunity to Build a Transatlantic Marketplace?
}

\author{
Christian Pitschas* \\ Attorney-at-Law, Geneva, Switzerland
}

\begin{abstract}
The European Union (EU) and the United States are currently negotiating a free-trade agreement, the so-called Transatlantic Trade and Investment Partnership (TTIP). These negotiations have to be seen in perspective, since a number of other - bilateral and plurilateral - trade deals are being pursued at the same time. All these negotiations point to a worrisome aspect: the World Trade Organisation's failure to come to a meaningful agreement in the Doha-round negotiations, in terms of market access, new rules and development. Like the Trans-Pacific Partnership (TPP), TTIP would stand out among the crowd of trade agreements because of the sheer volume of trade and investment flows across the Atlantic and the declared intention to boost regulatory cooperation and compatibility which is expected to bring the bulk of TTIP's economic benefits. However, the prospect of concluding such a transatlantic agreement raises many concerns; the public in the European Union and the United States fears that TTIP could undermine existing levels of protection in areas such as health and the environment and impinge on either side's "right to regulate". Moreover, questions are being posed as to what TTIP would mean for the multilateral trading system and how it would affect third countries, especially developing countries. Against this backdrop, this article addresses the following issues in relation to TTIP: the vision underlying the negotiations; the European Commission's negotiating mandate; the structure of the negotiations and their state of play; the Union's competence for concluding TTIP and whether it is shared with EU Member States; and finally TTIP's impact on the multilateral trading system and developing countries.
\end{abstract}

\section{CONTENTS}

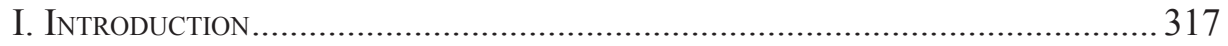

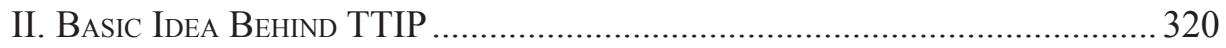

III. Negotiating Mandate of the European Commission................................ 323

* Attorney-at Law (Geneva), Lecturer, Freie Universität Berlin; Dr iur (Freie Universität Berlin); LLM (University of Georgia); LLB (Freie Universität Berlin). He can be reached at christian@pitschas.ch. 
IV. Negotiations' Structure and State of Play ................................................ 326

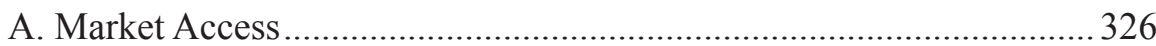

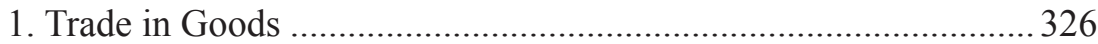

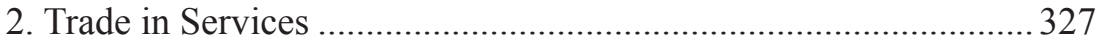

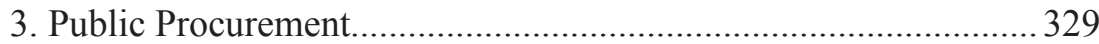

B. Regulatory Cooperation and Compatibility ………………..................330

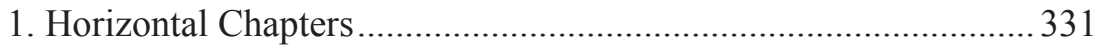

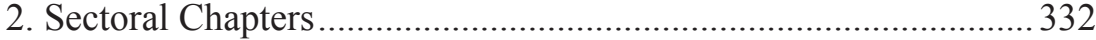

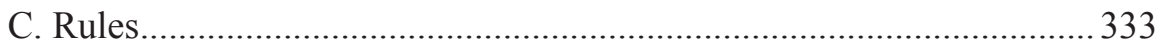

V. Exclusive Competence of the EuRopean Union for Concluding TTIP? ... 337

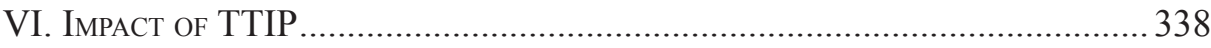

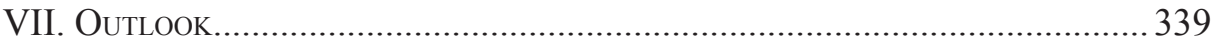




\section{INTRODUCTION}

The negotiations between the European Union (E.U.) and the United States of America (U.S.) regarding a free-trade agreement called the Transatlantic Trade and Investment Partnership (TTIP) were launched in 2013 and are ongoing. Both parties have declared their intention to finish the negotiations by the end of 2016 but this timeline seems unrealistic in view of the (number of) unresolved issues. ${ }^{1}$ Given the parties' willingness to negotiate a comprehensive and ambitious agreement, ${ }^{2}$ it is understandable that the negotiations are not yet completed. There is another reason, though, why the two sides have not yet been able to wrap up their talks: in parallel to their negotiations on TTIP, both parties have pursued further negotiations, at bilateral, plurilateral and multilateral level, which have sapped energy and resources.

At the multilateral level, the European Union and the United States were actively engaged in the Doha-round negotiations until the WTO Ministerial Conference in Nairobi at the end of 2015. ${ }^{3}$ At the plurilateral level, the European Union and the United States have been involved in the negotiations concerning a revised Information Technology Agreement (ITA 2), which were concluded in Nairobi, and are major players in the negotiations on a Trade in Services Agreement (TiSA) and an Environmental Goods Agreement (EGA), respectively. ${ }^{4}$ Moreover, the United States have strongly pushed for concluding another plurilateral agreement, the Trans-Pacific Partnership (TPP), which was signed in autumn last year; ${ }^{5}$ the current U.S. government hopes to receive the assent of U.S. Congress before the next U.S. President is sworn in. ${ }^{6}$ At the bilateral level, the European Union has

EU, US Negotiators Push for 2016 Deal, Though "TTIP Light" Not an Option, 20 Bridges Weekly 1 (May 4, 2016). In a speech before the summer break, Cecilia Malmström stated: “... we are prepared to make the political choices needed to close this deal by the end of the year. But we can only do that if we get the right result. We will not conclude a TTIP light; we want an agreement that will gain approval on both sides". TTIP: The Finish Line and How to Get There 2-3 (event at Atlantic Council, Washington D.C., Jun. 29, 2016), available at http://trade.ec.europa.eu/doclib/press/.

2 European Commission, Conclusion of the $13^{\text {th }}$ TTIP Negotiation Round 29 April 2016, Statement by Ignacio Garcia Bercero, EU Chief Negotiator for TTIP, available at http:// trade.ec.europa.eu/doclib/docs/2016/april/tradoc_154480.pdf. "It needs to be the most ambitious, balanced and comprehensive agreement ever concluded by either us or the US", id., at 2.

3 Trade Talks Lead to 'Death of Doha and the Birth of a New WTO', FinANCIAL Times, Dec. 21,2015 , at 4 .

4 On ITA2, see the WTO Ministerial Declaration on the Expansion of Trade in Information Technology Products, WT/MIN(15)/25, Dec. 16, 2015, available at https://www.wto. org/english/news_e/news15_e/ita_16dec15_e.htm. On TiSA, see the Report of the Commission on the $19^{\text {th }} \mathrm{TiSA}$ negotiation round Jul. 8 - 18, 2016, available at http:// ec.europa.eu/trade/policy/in-focus/tisa; on EGA, see the Commission's Report from the $15^{\text {th }}$ round of negotiations for an Environmental Goods Agreement (EGA), available at http://ec.europa.eu/trade/policy/policy-making/sustainable-development (last visited Sept. 29, 2016).

5 After TPP Deal Reached in Atlanta, Focus Shifts to Ratification, 19 BRIDGes WeEkLY 1 (Oct. 8, 2015).

6 Obama "Confident" of TPP Passage, Touting Trade Benefits During Asia Trip, 20 Bridges WeEkly 1 (May 26, 2016). For both economic and geopolitical reasons, it 
recently concluded negotiations on a free-trade agreement with Vietnam and is in negotiations with Japan concerning a free-trade agreement which both sides hope to finish before the end of $2016 .^{7}$

The aforementioned negotiations at bilateral and plurilateral level, including on TTIP, have a common denominator: World Trade Organization (WTO) Members' failure to achieve a breakthrough in the Doha-round negotiations, even after almost fifteen years since their inception in $2001 .^{8}$ While some limited progress has been made since then, notably in the area of trade facilitation, ${ }^{9}$ agreement in the crucial negotiating areas - non-agricultural market access, agriculture and services - is elusive. This sobering state of affairs has been demonstrated once again by the last WTO Ministerial Conference in Nairobi whose ministerial declaration lays bare the deep divisions among WTO Members over the question of how to continue these negotiations..$^{10}$ For the moment, the Doha-round negotiations are on hold and WTO Members pause for reflecting on the way forward in these negotiations. ${ }^{11}$

The realization that the Doha-round negotiations are lost in a maze of diverging interests has prompted a number of mostly developed countries, first and foremost the European Union and the United States, to seek different solutions, as is evidenced by the aforementioned negotiating initiatives. At the plurilateral level, the negotiations focus on single issues, such as trade in services or environmental goods, and are conducted among a group of countries which are willing to come to a meaningful agreement as quickly as possible; indeed, parties to the plurilateral

stands to reason that TPP is more important to the United States than TTIP, Gideon Rachman, Obama and the End of the Anglosphere, Financial Times, Apr. 26, 2016, at 9.

7 EU, Japan Leaders Call for Trade Talks to Conclude in 2016, 20 BRIDges WeEKLY 1 (May 4, 2016); see also The Commission's Report of the $16^{\text {th }}$ EU-Japan FTA/EPA Negotiating Round Apr. 11 - 20, 2016, available at http://ec.europa.eu/trade/policy/ countries-and-regions/countries/japan.

8 The Doha Round Finally Dies a Merciful Death, Financial Times, Dec. 22, 2015, at 8.

9 See WTO, Annual Report 2016, 83, available at https:/www.wto.org/english/res_e/ publications_e/anrep16_e.htm; WTO, World Trade Report 2015, Speeding up Trade: Benefits and Challenges of Implementing the WTO Trade Facilitation Agreement, available at https://www.wto.org/english/res e/publications_e/wtr15 e.htm. See also Antonia Eliason, The Trade Facilitation Agreement: A New Hope for the World Trade Organization, 14 World Trade ReV. 643-70 (2015).

10 The Ministerial Declaration of the WTO Ministerial Conference in Nairobi notes: "We recognize that many Members reaffirm the Doha Development Agenda ... and reaffirm their full commitment to conclude the DDA on that basis. Other Members do not reaffirm the Doha mandates, as they believe new approaches are necessary to achieve meaningful outcomes in multilateral negotiations. Members have different views on how to address the negotiations." WTO, Nairobi Ministerial Declaration of 19 December 2015, WT/ MIN(15)/DEC, para. 30, (Dec. 21, 2015), available at https:/www.wto.org/english/ thewto_e/minist_e/mc10_e/nairobipackage_e.htm.

11 Cecilia Malmström, The WTO after Nairobi - Your Views on the Way Ahead 3-4 (speech at the Civil Society Dialogue meeting on Apr. 26, 2016), available at http://trade. ec.europa.eu/doclib/html/154474.htm. But after the meeting of OECD ministers in early June 2016, the WTO DG Roberto Azevêdo called on WTO Members to move to the next stage by starting to "make concrete proposals on what they would like to see in terms of outcomes at the $11^{\text {th }}$ Ministerial Conference and beyond", Ministers Support Call for Intensified Efforts to Find Possible Areas of Agreement for MC 11, WTO 2016 News Items, Jun. 2, 2016, available at https:/www.wto.org/english/news_e/news16_e/ minis_02jun16_e.htm. 
negotiations on services (TiSA) and environmental goods (EGA) aim for their conclusion by the end of 2016. ${ }^{12}$ The noteworthy exception in this respect is TPP, since it is a comprehensive, deep integration agreement. At the bilateral level, the negotiations pursue a deep integration between two parties; a recent example is the Comprehensive Economic and Trade Agreement (CETA) which was concluded by the European Union and Canada. ${ }^{13}$

TTIP, too, is supposed to be a deep integration agreement, in terms of its level of market access, scope of regulatory cooperation and breadth of rules. Yet TTIP stands out for two reasons: the huge volume of trade and investment flows between the European Union and the United States,${ }^{14}$ and the intensity and density of regulatory cooperation sought by both parties. ${ }^{15}$ This is why TTIP is sometimes referred to as a "mega deal". The other mega deal is TPP whose economic weight and degree of deep integration, if it entered into force, would be similar to that of TTIP. ${ }^{16}$

However, TTIP's character as a mega deal entails a number of negative connotations, which are echoed in relation to TPP. One such connotation is related to the impact that TTIP could have on the multilateral trading system. In this regard, it is questioned whether the European Union and United States would neglect their (joint) responsibility for the latter system and instead focus their attention on their bilateral trade relationship. ${ }^{17}$ Another, albeit slightly contrary, concern is whether the European Union and United States would attempt to impose their bilateral rules on the multilateral trading system. ${ }^{18}$ Also, developing countries are wondering whether their preferential trading relationships with either of the two parties,

12 OECD, 2016 Ministerial Council Statement, Enhancing Productivity Through Inclusive Growth, para. 17, available at http://www.oecd.org/mcm.

13 See the information on CETA available on the Commission's website available at http:// ec.europa.eu/trade/policy/in-focus/ceta (last visited Jun. 10, 2016).

14 Memorandum of the European Commission, European Union and United States to Launch Negotiations for a Transatlantic Trade and Investment Partnership, Feb. 13, 2013, available at http://ec.europa.eu/trade/policy/in-focus/ttip/documents-and-events/ index_en.htm\#_documents [hereinafter European Commission's Memorandum (Feb. 13, 2013)] "Together, the European Union and the United States account for about half of the world GDP (47\%) and one third of global trade flows."

15 Press Release, Karel De Gucht, Transatlantic Trade and Investment Partnership (TTIP) Solving the Regulatory Puzzle (Speech/13/801, Oct. 10, 2013), available at http:// ec.europa.eu/trade/trade-policy-and-you/publications; Cecilia Malmström, TTIP on Track 2-3, Speech at Bruegel TTIP Workshop (Mar. 12, 2015), available at http://trade.ec.europa. eu/doclib/press/index.cfm?id=1275\&title=Speech-TTIP-On-Track; Cecilia Malmström, Trade in the $21^{s t}$ Century: The Challenge of Regulatory Convergence (speech, Mar. 19, 2015), available at http://ec.europa.eu/trade/trade-policy-and-you/publications.

16 See Jeffrey J. Schott, Understanding the Trans-Pacific Partnership: An Overview, PIIE (May 3-5, 2016), https://piie.com/research/trade-investment/trans-pacific-partnership; See also Hans Günter Hilpert, Einigung auf ein Transpazifisches Freihandelsabkommen, 86 SWP-Aktuell, (Oct. 2015), available at http://www.swp-berlin.org/fileadmin/ contents/products/aktuel1/2015A86_hlp.pdf.

17 Hendrik Kafsack, In den Krallen des Chlorhuhns, Frankfurter Allgemeine Zeitung, Feb. 20, 2014, at 9; Marcel Fratzscher, Europe's Free Trade Deal with America Could be a Costly Error, Financial Times, Feb. 22, 2013, at 9.

18 See Christian Pitschas, Transatlantic Trade and Investment Partnership Agreement and the Development of International Standards, 6 EuR. Y.B InT'L Econ. L. 161, 168-69, 183-85 (2015). 
especially tariff preferences unilaterally enjoyed by them in the European Union and the United States, will be adversely affected by any market opening that the European Union and the United States exclusively grant each other. ${ }^{19}$

But the concerns with TTIP do not stop there. In the European Union in particular, the public in many Member States is worried about what TTIP might mean for them. Three issues seem to attract particular attention: (i) the transparency of the negotiations, (ii) the level of protection in areas such as health, environment, food, and data protection, and (iii) the rules on investment protection and the role of investor-to-state dispute settlement (ISDS) with respect to regulation for legitimate public policy objectives and its relationship with the domestic judicial system..$^{20}$ The public debate on these and other topics is fierce, although sometimes misinformed and misguided.

Against this backdrop, this article seeks to approach TTIP by looking into the following issues:

- What is the basic idea behind TTIP, and on what basis does the European Commission negotiate with the United States?

- How are the negotiations structured, and how far have they advanced?

- Would TTIP fall within the EU's exclusive competence for common commercial policy, or would it be a "mixed agreement" which has to be ratified by all EU Member States?

- What impact would TTIP have on the multilateral trading system in general and developing countries in particular?

\section{BASIC Idea BeHIND TTIP}

In November 2011, the European Union and the United States established a high level working group on jobs and growth (HLWG). ${ }^{21}$ The HLWG was asked to pinpoint "policies and measures" that would increase transatlantic trade so as to stimulate economic growth, create jobs and enhance competitiveness. ${ }^{22}$ After

19 See the preliminary analysis by Jim Rollo, Max Mendez Parra \& Sarah Ollerenshaw, The Transatlantic Trade and Investment Partnership: Implications for LDCs and Small States, 102 Commonwealth Trade Hot Topics (2013), available at http://www. thecommonwealth-ilibrary.org/commonwealth/trade/trade-hot-topics_20719914. They suggest that the loss of market share or deterioration in terms of trade on EU and U.S. markets are likely to be small, $i d$. at 6 .

20 See Cecilia Malmström, TTIP for the Business Community, 4, Speech at the Swedish Enterprise Event (May 24, 2016), available at $\mathrm{http}$ //ec.europa.eu/trade/policy/in-focus/ ttip/documents-and-events/index_en.htm\#_documents); Transatlantic Trade: Why a Deal is Hard to Strike, Financial Times, Apr. 26, 2016, at 2; Public Cast Doubt on EUUS Trade Deal, Financial Times, Apr. 10, 2014, at 4.

21 European Commission's Memorandum (Feb. 13, 2013), supra note 14.

22 High Level Working Group on Jobs and Growth, Final Report (Feb. 11, 2013), 1, available at $\mathrm{http} / /$ ec.europa.eu/trade/policy/in-focus/ttip/documents-and-events/index en.htm\#negotiation-rounds. 
consultations with various stakeholders, public and private, from both sides of the Atlantic, the HLWG issued its final report in early February 2013.

The final report recommended that the European Union and the United States commence negotiations on a "comprehensive, ambitious agreement that addresses a broad range of bilateral trade and investment issues, including regulatory issues, and contributes to the development of global rules." ${ }^{23}$ This recommendation is based on the assumption that a transatlantic agreement of this kind "could generate new business and employment by significantly expanding trade and investment opportunities in both economies." ${ }^{24}$ Achieving this objective would necessitate opening further the markets on both sides of the Atlantic as well as promoting regulatory cooperation and coherence with a view to "moving progressively toward a more integrated transatlantic marketplace." $" 25$ In addition to these economic considerations, the final report noted that "the extraordinarily close strategic partnership between the United States and Europe" would be strengthened by concluding such an agreement. ${ }^{26}$

In light of these goals, the final report identified three general themes for a comprehensive trade and investment agreement:

- market access,

- $\quad$ non-tariff barriers (NTBs) and regulatory issues, and

- $\quad$ rules and principles relating to global trade. ${ }^{27}$

As regards market access, a traditional subject of free-trade agreements, the final report stated that obstacles relating to goods, services, investment and procurement should be addressed in a manner that "goes beyond what the United States and the European Union have achieved in previous trade agreements." 28 Thus, there is an expectation that TTIP should lead to an unprecedented level of market access. Given that the markets of the European Union and the United States are relatively open, a further opening of these markets would require both parties to make concessions in those sectors that they consider as sensitive, in particular as regards services and government procurement.

In respect of NTBs and regulatory issues, a somewhat more recent phenomenon of free-trade agreements, the final report noted that regulatory cooperation, i.e. cooperation between regulators / regulatory authorities, and greater regulatory compatibility (through means such as equivalence, mutual recognition and harmonization) are key in reducing administrative burdens and compliance costs arising from existing regulations, while safeguarding "the levels of health, safety, and environmental protection that each side deems appropriate." ${ }^{\prime 29}$ In this respect, the final report singled out a number of elements which should be the focus of negotiations:

\footnotetext{
Id. at 6.

$I d$. at 2 .

Id. at 3 .

$I d$. at 2 .

$I d$.

$I d$.

$I d$. at 3 .
} 
- $\quad$ chapters on technical barriers to trade (TBT) and sanitary and phytosanitary (SPS) measures, which build on the corresponding agreements of the WTO but include additional ("WTO plus") commitments,

- a horizontal chapter on good regulatory practices,

- $\quad$ sector-specific chapters with targeted rules for selected goods and services sectors, and

- $\quad$ an institutional framework for future dialogue on regulatory cooperation and compatibility. ${ }^{30}$

As regards rules and principles relating to global trade, the final report took the view that such rules and principles "would also contribute to the progressive strengthening of the multilateral trading system." 31 According to the final report, those rules and principles should address a host of issues, including intellectual property rights, environment and labour, customs and trade facilitation, competition policy, state-owned enterprises, raw materials and energy, localization barriers to trade, small and medium-sized enterprises, and transparency. ${ }^{32}$

The HLWG's final report spells out, in a nutshell, the reasons that speak in favour of negotiating a transatlantic free-trade agreement. These reasons are both economic and political in nature. To a large extent, the economic benefit would come from enhancing the regulatory cooperation and compatibility between the European Union and the United States. ${ }^{33}$ Yet it is exactly this regulatory part many European and American citizens are concerned about, as they fear a loss of regulatory autonomy and a lowering of safety standards. The European Commission insists, however, that TTIP would not undermine European standards in areas such as the environment and public health but rather maintain parties' "right to regulate" so as to pursue their legitimate public policy objectives. ${ }^{34}$ Nonetheless, one wonders

\section{$I d$. at 4 . \\ Id. at 5 .}

Id. at 5-6.

3 European Commission's Memorandum (Feb. 13, 2013), supra note 14, notes that "studies show that the additional cost burden due to such regulatory differences is equivalent to a tariff of more than $10 \%$, and even $20 \%$ for some sectors, whereas classic tariffs are at around 4\%". Memorandum of the European Commission, Member States Endorse EU-US Trade and Investment Negotiations, Jun. 14 2013, available at http://ec.europa.eu/trade/policy/infocus/ttip/documents-and-events/index_en.htm\#negotiation-rounds [hereinafter European Commission's Memorandum (Jun. 14, 2013)] states that the "regulatory area is where the highest potential economic benefit lies". Economic analysis commissioned by the Commission estimates that up to $80 \%$ of the expected economic benefits would result from eliminating or reducing non-tariff barriers, see Transatlantic Trade and Investment Partnership, The ECONOMIC ANALYSIS ExPlaIned 6, (Sept. 2013), available at http://ec.europa.eu/trade/policy/ in-focus/ttip/documents-and-events/index en.htm\#economic-benefits. See also Chris Giles, In Trade, Geography Matters More Than You Think, FinAncial Times, Feb. 25, 2016, at 9.

34 European Commission, TTIP Explained (Mar. 19, 2015), 2 (available at http://trade. ec.europa.eu/doclib/docs/2014/may/tradoc_152462.pdf; TTIP round 11, Statement by EU Chief Negotiator Ignacio Garcia Bercero, (Miami, Oct. 23, 2015), available at http://ec.europa.eu/trade/policy/in-focus/ttip/documents-and-events/index_en.htm\# negotiation-rounds: "The cooperation is only possible if the level of protection for citizens stays the same or improves ... Any form of regulatory cooperation will not change the way we regulate on public policies such as food safety or data privacy. Nor will it affect legislative processes or the independence of our regulators", id. at 1-2. 
whether the HLWG did not underestimate foreseeable public opposition against closer regulatory cooperation and compatibility as an immediate component of a transatlantic agreement instead of opting for a more cautious approach by establishing procedural rules in the agreement that would pave the way for future discussions on a more integrated transatlantic approach to regulation.

On the trade policy side, the HLWG envisages the development of rules and principles that would not only be applicable to the bilateral transatlantic trade relationship but constitute a template for similar rules at the multilateral level. Indeed, representatives of both parties have stressed several times since the negotiations were launched that TTIP should set forth "global" rules on emerging trade issues where no multilateral rules yet exist. ${ }^{35}$ Interestingly, the same approach is followed by TPP, as was emphasised by U.S. President Barack Obama. ${ }^{36}$ Nevertheless, other countries may feel rather uncomfortable with the notion that two major trading powers aspire to define, within a purely bilateral context, rules that are intended also to serve as blueprint for the multilateral context.

\section{Negotiating Mandate of the European Commission}

Shortly after the release of the HLWG's final report, the EU Council adopted the negotiating directives for the Commission, the so-called negotiating mandate. ${ }^{37}$ It provides binding guidance to the Commission for the negotiations, in terms of the negotiating objectives as well as the negotiating areas. Initially, the negotiating mandate was not made public for reasons of confidentiality. In the meantime, the

35 Joe Biden, We Cannot Afford to Stand on the Sidelines of Trade, Financial Times, Feb. 28, 2014, at 9 ("We have an opportunity to shape the path of global commerce to spread our values and benefit our people, and we should seize it"); Karel De Gucht, The Transatlantic Trade and Investment Partnership: The Real Debate 4 (Speech/14/406, May 22, 2014), available at http://trade.ec.europa.eu/doclib/cfm/doclib_search. cfm\#more-criteria; ("We, the European Union, want to keep our place in the world. And if we want to continue to shape the norms, rules, standards and disciplines that are so important in a globalised economy, we have to realise that we cannot do this without partners. If the two strongest economies in the world agree on something, then that provides a very strong basis to start talking with the rest of the world"); Malmström, TTIP on Track, supra note 15, at 3 ("Our idea here is to establish disciplines that would set gold standards ... and for these, in many cases, to be a starting point for future negotiations on global rules"); Malmström, TTIP for the Business Community, supra note 20, at 4 ("Both the EU and the US believe in open markets, in the rule of law and in high standards of regulatory protection. TTIP can help us ensure that those principles are reflected in global standards in the future").

36 "The TPP means that America will write the rules of the road in the $21^{\text {st }}$ century. When it comes to Asia ... the rulebook is up for grabs. And if we don't pass this agreement - if America doesn't write those rules - then countries like China will. And that would only threaten American jobs and workers and undermine American leadership around the world", quoted in: TPP Debate Ramps up Following Public Release of Trade Deal Text 19 BRIDGES WEEKLY 7 (Nov. 12, 2015).

37 European Commission's Memorandum (Jun. 14, 2013), supra note 33. 
negotiating mandate has been published, for the sake of transparency. ${ }^{38}$ It should be noted that the negotiating mandate does not contain any surprises, at least not to the informed observer, as it essentially confirms the objectives put forward by the HLWG's final report. Nonetheless, the publication is useful in that it dispels any suspicion whether the European Union might pursue secret goals in these negotiations.

Pursuant to the negotiating mandate, the "agreement shall provide for the reciprocal liberalisation of trade in goods and services as well as rules on trade-related issues, with a high level of ambition going beyond existing WTO commitments. ${ }^{" 39}$ Next, the negotiating mandate calls for a preamble that underlines the "common principles and values" of the parties, including their right to take measures necessary to achieve "legitimate public policy objectives on the basis of the level of protection of health, safety, labour, consumers, the environment and the promotion of cultural diversity ... that they deem appropriate. ${ }^{" 40}$ Further, the negotiating mandate states that the EU objectives consist of increasing trade and investment between the European Union and the United States "through increased market access and greater regulatory compatibility and setting the path for global standards." ${ }^{41}$ Accordingly, the agreement should consist of three core components, namely market access, NTBs and regulatory issues, and rules. ${ }^{42}$

The market access component should cover: (i) trade in goods, (ii) trade in services and establishment, (iii) investment protection, and (iv) public procurement. As regards trade in goods, an elimination of "all duties on bilateral trade" is envisaged, with "options for the treatment of the most sensitive products, including tariff rate quotas." ${ }^{43}$ As regards trade in services, the negotiating mandate directs the Commission to seek "the highest level of liberalisation captured in existing FTAs ... while achieving new market access by tackling remaining long-standing market access barriers, recognising the sensitive nature of certain sectors." ${ }^{\prime 4}$ Audiovisual services, however, are not covered. ${ }^{45}$ In the field of investment protection, the negotiations should be conducted "on the basis of the highest levels of liberalisation and highest standards of protection that both Parties have negotiated to date." ${ }^{46}$ But a caveat applies to ISDS: its inclusion "will depend on whether a satisfactory solution ... is achieved." ${ }^{47}$ In the area of public procurement, the negotiations should aim for "maximum ambition" by seeking enhanced mutual access "at all administrative levels (national, regional and local)." ${ }^{48}$ Moreover, the public procurement chapter should address "local content or local production requirement,

38 Council of the EU, Directives for the Negotiation on the Transatlantic Trade and Investment Partnership Between the European Union and the United States of America, 11103/13 DCL 1, (Oct. 9, 2014), available at http://ec.europa.eu/trade/policy/in-focus/ ttip/documents-and-events/index_en.htm\#eu-position.

Id. para. 3 .

Id. para. 6 .

Id. para. 7.

Id. para. 5.

Id. para. 10.

Id. para. 15.

Id. para. 21.

Id. para. 22

$I d$.

Id. para. 24. 
including Buy America(n) provisions, ... and existing carve-outs, including for small and medium-sized enterprises." 49

The agreement's second component on NTBs and regulatory issues should aim for an "ambitious level of regulatory compatibility for goods and services ... and enhanced cooperation between regulators." ${ }^{50}$ However, this has to be "without prejudice to the right to regulate." ${ }_{11}$ In addition to provisions on SPS measures and TBT, the agreement should encompass "cross-cutting" rules on regulatory coherence and transparency that allow for "efficient, cost-effective, and more compatible regulations for goods and services." ${ }^{52}$ Moreover, regulatory differences in specific goods and services sectors should be diminished through "harmonisation, equivalence, or mutual recognition, where appropriate." ${ }^{53}$ Also, a framework for "guiding further work on regulatory issues" should be set up. ${ }^{54}$ The rules agreed on regulatory cooperation and compatibility ought to be "binding on all regulators and other competent authorities of both Parties." 55

The agreement's third component on rules should cover a number of issues, in particular intellectual property rights, trade and sustainable development, and customs and trade facilitation. As regards intellectual property rights, the agreement should provide for "enhanced protection and recognition of EU Geographical Indications." "F Further, the "labour and environmental aspects of trade and sustainable development" should be addressed by the agreement. ${ }^{57}$ In the area of customs and trade facilitation, the parties' commitments are expected to go beyond "commitments negotiated in the WTO." 58

In sum, the negotiating mandate reflects the idea that TTIP should lead to a comprehensive and deep economic integration between the European Union and the United States. While this goal has been pursued already in the Union's trade relations with other countries, such as South Korea, Singapore, and, most recently, Canada, TTIP would take the idea even a step further because of the scope and extent of the transatlantic trade and investment relationship. To achieve said goal, the negotiations should pursue an ambitious outcome in terms of market access for goods and services, possibly going beyond the level of market access achieved under other free-trade agreements of either the European Union or the United States, and lead to a significantly enhanced cooperation between the European Union and the United States on the way they regulate, including through increased cooperation between the respective regulatory authorities, common rules for the process of designing new regulatory measures and an elimination or reduction of existing regulatory differences in specific goods and services sectors.
Id.
Id. para. 25.
Id.
$I d$.
$I d$.
Id. para. 26
Id. para. 27.
Id. para. 29.
Id. para. 31 .
Id. para. 34 . 


\section{Negotiations' Structure and State of Play}

The structure of the negotiations follows the agreement's prospective content. Accordingly, three main parts may be discerned. ${ }^{59}$ The first part is about market access. Negotiations on market access relate to trade in goods, including customs duties and rules of origin, services and public procurement. The second part concerns regulatory cooperation and compatibility. Negotiations in this area are two-pronged: they seek to establish horizontal as well as sector-specific disciplines. The third part relates to rules on various subject-matters, including investment protection and ISDS, which both the HLWG's final report and the EU's negotiating mandate initially envisaged as part of the market access negotiations.

\section{A. MARKET ACCESS}

\section{Trade in Goods}

There are two main targets in this area: eliminating customs duties and aligning rules of origin.

While the average rate of customs duties applied by both negotiating parties is rather low, at around 5\% ad valorem for EU duties and 3.5\% ad valorem for U.S. duties, ${ }^{60}$ even the elimination of these relatively low customs duties would result in tangible economic benefits given the magnitude of transatlantic trade flows. ${ }^{61} \mathrm{In}$ addition, there are product categories, including high value goods and agricultural products, for which customs duties are significantly higher, in some cases even prohibitively high (i.e. higher than $100 \%$ ad valorem). ${ }^{62}$ The idea is to eliminate the vast majority of customs duties ( $97 \%$ of tariff lines, according to the parties' revised market access offers $)^{63}$ immediately as of the entry into force of the agreement and to gradually eliminate or reduce the remaining customs duties. ${ }^{64}$ In order to create a commercially viable market access for those sensitive (agricultural) goods for which customs duties would not be eliminated or reduced, tariff quotas with preferential in-quota tariffs would be provided for. ${ }^{65}$

59 European Commission, Inside TTIP. An Overview and Chapter-by-Chapter Guide in Plain English 9 (2015), available at http:/trade.ec.europa.eu/doclib/docs/2015/july/ tradoc_153635.pdf.

60 European Commission's Memorandum (Jun. 14, 2013), supra note 33.

61 European Commission, TTIP Explained, supra note 34, at 1; Malmström, TTIP for the Business Community, supra note 20, at 2.

62 European Commission, Inside TTIP, supra note 59, at 12.

63 European Commission, The Transatlantic Trade and Investment Partnership (TTIP) State of Play 4, (Apr. 27, 2016, available at http://ec.europa.eu/trade/policy/in-focus/ ttip/documents-and-events/index_en.htm\#transparency.

64 European Commission, National Treatment and Market Access for Goods in TTIP. An Explanatory Note 2 (Mar. 21, 2016, updated on Mar. 22, 2016); European Commission, Report of the $13^{\text {th }}$ Round of Negotiations for the Transatlantic Trade and Investment Partnership 4, May 24, 2016, available at http://ec.europa.eu/trade/policy/in-focus/ttip/ documents-and-events/index_en.htm\#negotiation-rounds.

65 European Commission, National Treatment and Market Access for Goods in TTIP, supra note 64 , at 2. 
E.U. and U.S. rules of origin differ in their approach to determining where products have been manufactured. The goal is to align them and facilitate their application, while taking into account the needs of industries and considering the potential scope for cumulation ${ }^{66}$ with third countries that have concluded freetrade agreements with both the European Union and the United States. ${ }^{67}$ The most recent discussions concerning rules of origin addressed: general provisions, origin procedures and product specific rules. ${ }^{68}$

\section{Trade in Services}

The services industry accounts for more than $60 \%$ of economic activity in both the European Union and the United States, ${ }^{69}$ and they are the world's largest exporters of services. Both sides therefore are keen to obtain greater access to each other's services sectors, irrespective of the fact that services already account for a considerable share of transatlantic trade, with the European Union being the main services exporter to the United States and vice versa ${ }^{70}$ At the same time, trade in services is strongly affected by domestic regulation of services. ${ }^{71}$ Consequently, both parties contemplate improving existing disciplines for domestic regulatory measures as well as introducing new disciplines in this respect. ${ }^{72}$

With respect to market access, the objective is twofold: ensuring reciprocal market access at a level corresponding to the highest level of liberalisation bound under existing EU and U.S. free-trade agreements and tackling long-standing market access barriers. ${ }^{73}$ The European Union also strives for better market access for professional service providers (mode 4). ${ }^{74}$ To this end, the EU's (revised) services offer contains commitments on market access (using a positive list approach) and commitments on most-favoured nation treatment and national treatment (using a negative list approach). ${ }^{75}$

66 The term "cumulation" refers to those rules of origin that allow components from and processing in certain third countries to be considered for the acquisition or maintenance of preferential origin (definition according to the customs glossary of European Commission's DG TAXUD, available at http://ec.europa.eu/taxation_customs/glossary/ customs-glossary_en).

67 Council of the EU, Negotiation Directives, supra note 38, para. 11; European Commission, Inside TTIP, supra note 59, at 16.

68 European Commission, Report of the $13^{\text {th }}$ Round of Negotiations, supra note 64, at 6-7.

69 European Commission, Inside TTIP, supra note 59, at 13.

70 European Commission, Reading Guide. Publication of the EU Proposal on Services, Investment and E-commerce for the Transatlantic Trade and Investment Partnership 1, (Jul. 31, 2015), available at http://trade.ec.europa.eu/doclib/press/index. cfm?id=1230\#part-1-services.

71 See WTO, Disciplines on Domestic Regulation Pursuant to GATS Article VI.4, para. 2 (Jun. 2011), available at https://www.wto.org/english/tratop_e/serv_e/dom_reg_negs_e. $\mathrm{htm}$. See also Martin Wolf, Unilateral Free Trade is a Dangerous Fantasy, FinanCIAL Times, Jun. 10, 2016, at 9.

72 European Commission, Inside TTIP, supra note 59, at 13-14.

73 Council of the EU, Negotiation Directives, supra note 38, para. 15.

74 European Commission, Inside TTIP, supra note 59, at 13.

75 European Commission, Reading Guide, supra note 70, at 3-4 (the EU's revised offer sets forth reservations for certain sectors where quantitative limitations or discriminatory measures may be maintained or introduced in the future; conversely, a ratchet clause 
The EU's (revised) offer also includes a so-called "public utilities reservation" that allows Member States to maintain or introduce quantitative limitations and discriminatory measures in relation to public health, public education, and social services as well as the management, collection, purification and distribution of water, thereby granting them full discretion in organising and regulating the provision of those services. ${ }^{76}$ This "carve-out" for public services corresponds to a joint statement on public services made by Trade Commissioner Malmström and USTR Froman. ${ }^{77}$ The European Union has not made any commitments in the audiovisual services sector. However, in spite of having exchanged revised services offers so far, the level of market access offered by either side still appears to be unsatisfactory when measured against the abovementioned benchmark. ${ }^{78}$

Negotiations address the domestic regulation of services because of its pervasive effect on services trade. ${ }^{79}$ In this respect, one objective is to elaborate on existing multilateral disciplines under GATS, in particular regarding licensing requirements and procedures so as to ensure a transparent, objective and expeditious treatment of applications. ${ }^{80}$ The other objective consists of devising disciplines on domestic regulation in particular services sectors, including telecoms, e-commerce, financial services, postal and courier services ${ }^{81}$ Moreover, both parties attempt to come up with rules for the mutual recognition of professional qualification requirements. ${ }^{82}$

applies to some sectors, thereby making future liberalization binding). On the different approaches to scheduling services commitments used in free-trade agreements, see European Commission, Services and Investment in EU Trade Deals. Using 'Positive' and 'Negative' Lists (Apr. 2016, available at http://trade.ec.europa.eu/doclib/press/ index.cfm?id=1230\#part-1-services.

76 European Commission, Reading Guide, supra note 70, at 2. See also European Commission, Protecting Public Services in TTIP and Other EU Trade Agreements, Jul. 13, 2015, available at $\mathrm{http}$ ://trade.ec.europa.eu/doclib/press/index.cfm?id=1230\#part-1-services.

77 Joint Statement on Public Services, Mar. 20, 2015, available at http://ec.europa.eu/trade/ policy/in-focus/ttip/documents-and-events/index_en.htm\#eu-position ("Furthermore, no EU or U.S. trade agreement requires governments to privatize any service, or prevents governments from expanding the range of services they supply to the public. Moreover, these agreements do not prevent governments from providing public services previously supplied by private service suppliers; contracting a public service to private providers does not mean that it becomes irreversibly part of the commercial sector").

78 European Commission, Transatlantic Trade \& Investment Partnership Advisory Group, Meeting Report 19 May 2016, at 3, available at http://trade.ec.europa.eu/doclib/ docs/2016/may/tradoc_154553.pdf.

79 See Hildegunn K. Nordås, Services Trade Restrictiveness Index (STRI): The Trade Effect of Regulatory Differences, 189 OECD Trade Policy Papers 5 (2016) (pointing out: "as the border restrictions on services trade and investment come down, regulatory cooperation could make the most significant contribution to reducing services trade costs going forward"). See also New Global Trade Under Old National Rules, Financial Times, Mar. 7, 2016, at 8.

80 European Commission, Inside TTIP, supra note 59, at 13; see also European Commission, Report of the $13^{\text {th }}$ Round of Negotiations, supra note 64, at 6.

81 European Commission, Inside TTIP, supra note 59, at 14; see also Commission, Report of the $13^{\text {th }}$ Round of Negotiations, supra note 64, at 5-6. It is unclear, however, whether regulatory cooperation in financial services would be part of TTIP, see European Commission, TTIP Advisory Group, supra note 78, at 3.

82 European Commission, Report of the $13^{\text {th }}$ Round of Negotiations, supra note 64, at 5 . 
In this context, it is interesting to note that the European Union and the United States are also major proponents of the plurilateral TiSA negotiations which run in parallel to the TTIP negotiations. The former negotiations also aim for an ambitious outcome in terms of market access, reflecting the actual level of existing liberalization, and enhanced disciplines on domestic regulation. ${ }^{83}$ Yet the initial market access offers submitted by TiSA negotiating parties seem to have been rather disappointing compared to the officially stated goal, and even the revised market access offers, while constituting an improvement, do not seem to meet the initial expectation. ${ }^{84}$ In contrast, TiSA negotiating parties appear to have made more headway on disciplines for domestic regulation. ${ }^{85}$ It is recalled that TiSA negotiating parties seek to conclude their negotiations by the end of $2016 .{ }^{86}$

\section{Public Procurement}

Next to services, market access in public procurement holds the biggest potential for new economic opportunities. This potential stems from the fact that public procurement stands for a very sizeable portion of GDP both in the European Union and the United States, and their respective market access commitments in the framework of the revised Government Procurement Agreement of the WTO leave room for some (significant) improvement. ${ }^{87}$ It is not surprising, therefore, that the European Union strongly insists on getting better access to the U.S. public procurement market, especially at the sub-federal level, by addressing the various restrictions and exceptions that are in place in this area. ${ }^{88}$

As effective access to the public procurement market hinges on transparency, a further necessary condition for the European Union is increased transparency of public procurement opportunities in the United States which lack a single central electronic publication medium. ${ }^{89}$ However, negotiations on market access in public

83 Memorandum of the European Commission, Negotiations for a Plurilateral Agreement on Trade in Services 2 (Feb. 15, 2013), available at http://ec.europa.eu/trade/policy/ in-focus/tisa (last visited Jun. 14, 2016). See Rudolf Adlung, The Trade in Services Agreement (TiSA) and Its Compatibility with GATS: An Assessment Based on Current Evidence, 14 World Trade Review 617-41 (2015).

84 European Commission, Civil Society Dialogue, Meeting on TiSA 1 (Dec. 11, 2015, available at http://rade.ec.europa.eu/civilsoc/meetlist.cfm\#year-2015. Revised market access offers were submitted in early May 2016 and discussed at the $18^{\text {th }}$ negotiating round, European Commission, Report of the $18^{\text {th }}$ TiSA Negotiation Round, 26 May - 3 June 2016, 1-2, available at $\mathrm{http} / / / \mathrm{ec}$.europa.eu/trade/policy/in-focus/tisa.

85 European Commission, Report of the $17^{\text {th }}$ TiSA negotiation round, supra note 4, at 1-2; European Commission, Report of the $18^{\text {th }}$ TiSA Negotiation Round, supra note 84, at 2-3.

86 Services Trade in Focus as TISA, TTIP, RCEP Aim for 2016 Conclusion 20 BRIDGES WEEKLY 1 (Mar. 4, 2016).

87 European Commission, Inside TTIP, supra note 59, at 15; European Commission, TTIP - State of Play, supra note 63, at 5.

88 Council of the EU, Negotiation Directives, supra note 38, para. 24. In her speech to the Atlantic Council in Washington D.C. on Jun. 29, 2016, Cecilia Malmström emphasized again the importance the EU attaches to gaining market access to the U.S. government procurement market at all levels of government: "An ambitious outcome that creates new opportunities at the federal and state level is a sine qua non", supra note 1, at 3 .

89 European Commission, Report of the $13^{\text {th }}$ Round of Negotiations, supra note 64, at 5; European Commission, TTIP Advisory Group, supra note 78, at 3. 
procurement seem to have run into difficulties. ${ }^{90}$ Whether these difficulties can be overcome is an open question, given the constitutional constraints of the U.S. government in influencing government procurement policies at the sub-federal level. ${ }^{91}$

\section{B. REGULATORY COOPERATION AND COMPATIBILITY}

The second part of the intended TTIP agreement would consist of two sections: one section would contain horizontal chapters, whereas the other section would comprise nine sector specific chapters..$^{92}$ Both the horizontal and the sectoral chapters pursue the overarching objective of establishing principles for closer cooperation between regulatory authorities on both sides of the Atlantic, including in an international context, and greater compatibility of regulations adopted by both parties. ${ }^{93}$ But neither closer regulatory cooperation nor greater regulatory compatibility is supposed to negate or undermine either side's right to regulate or set the level of protection it deems appropriate. ${ }^{94}$

It is assumed that closer regulatory cooperation and greater regulatory compatibility would: (i) render the process of adopting regulations more transparent, while taking the interests of the other side and interested parties into account, (ii) minimize unnecessary regulatory differences and lead to more effective and better regulation, (iii) reduce compliance costs for the economic operators affected by those regulations, (iv) allow for greater competition and exploitation of economies of scale and scope, and (v) ultimately raise the quality of goods and services. ${ }^{95}$

90 European Commission, TTIP - State of Play, supra note 63, at 5. See TTIP and the End of the Year, 25 Washington Trade Daily 2 (Jun. 15, 2016). The EU chief negotiator for TTIP acknowledged at the end of the $14^{\text {th }}$ negotiation round that: “... we are still very far from achieving that goal", i.e. substantial improvements in market access at all levels of government, Conclusion of the $14^{\text {th }}$ TTIP Negotiation Round 15 July 2016. Statement by Ignacio Garcia Bercero, EU Chief Negotiator for TTIP, at 2, available at http://ec.europa.eu/trade/policy/in-focus/ttip.

91 See Hans-Joachim Prie $\beta$, Neuerungen des Agreement on Government Procurement, in Die WTO nach Bali - Chancen und Risiken 105, 113 (Dirk Ehlers, Christian Pitschas \& Hans-Michael Wolffgang eds., 2015).

92 European Commission, Inside TTIP, supra note 59, at 17.

93 Id. at 18.

$94 \quad I d$. The EU chief negotiator stated categorically at the end of the $14^{\text {th }}$ negotiation round: "Cooperation will only be possible if the level of protection for citizens improves, or at least stays the same", Conclusion of the $14^{\text {th }}$ TTIP Negotiation Round 15 July 2016, supra note 90 , at 2.

95 Id. See also European Commission, Regulatory Cooperation in TTIP: The Benefits 2 (Mar. 21, 2016), available at http://trade.ec.europa.eu/doclib/press/index. $\mathrm{cfm}$ ?id=1230\#regulatory-cooperation); Daniel R. Pérez \& Susan E. Dudley, Experiences in International Regulatory Cooperation: Benefits, Limitations, and Best Practices 4-5 Regulatory StUdies, available at https://regulatorystudies.columbian.gwu.edu/us-euregulatory-cooperation-lessons-and-opportunities (last visited Jun. 15, 2016); Wolf, supra note 71. 


\section{Horizontal Chapters}

The horizontal section would comprise three (or four) chapters: a chapter on good regulatory practices and regulatory cooperation (which could possibly be split into two chapters), a chapter on TBT and a chapter on SPS measures. ${ }^{96}$ The first chapter would establish principles on good regulatory practices which are meant to promote good governance in the regulatory process by strengthening transparency, predictability and accountability, including through prior information on planned regulatory measures, consultation with stakeholders and the public, and ex ante as well as ex post impact assessment. ${ }^{97}$ Such principles are not a new topic in free trade agreements: they are contained, for example, in some of the free-trade agreements concluded by the European Union and the United States and a regular feature of the discussions among WTO Members in the TBT Committee. ${ }^{98}$

Moreover, the first (or second) chapter would set forth rules on how regulators should cooperate, including through exchange of information and a commitment to assess the regulatory measures proposed by the other side as to their merits. ${ }^{99}$ Furthermore, the European Union proposes that the chapter on regulatory cooperation should include an institutional mechanism, such as a regulatory cooperation body, which would be composed of representatives of EU and U.S. regulatory authorities and act as a forum for exchange and the setting of priorities but without decisionmaking power. ${ }^{100}$ Importantly, the chapter(s) on good regulatory practices and regulatory cooperation would not be subject to the dispute settlement system of the intended TTIP agreement. ${ }^{101}$ The European Union and the United States have consolidated their respective texts on both good regulatory practices and regulatory cooperation, but so far their positions seem to be closer on the former issue. ${ }^{102}$

The second and third chapters would set out commitments on TBT and SPS measures, building on, but going beyond, the corresponding multilateral trade agreements in Annex $1 \mathrm{~A}$ to the WTO Agreement. ${ }^{103}$ In the area of TBT, different

96 European Commission, Inside TTIP, supra note 59, at 17.

97 European Commission, Good Regulatory Practices (GRPS) in TTIP. An Introduction to the EU's Revised Proposal 2 (Mar. 21, 2016), available at http://trade.ec.europa.eu/ doclib/press/index.cfm?id=1230\#regulatory-cooperation.

98 Id. at 2-3; WTO, Committee on Technical Barriers to Trade, Seventh Triennial Review of the Operation and Implementation of the Agreement on Technical Barriers to Trade Under Article 15.4, 2-3 (G/TBT/37, 3 December 2015), available at https://www.wto. org/english/tratop_e/tbt_e/tbt_triennial_reviews_e.htm (last visited Jun. 15, 2016); Committee on Technical Barriers to Trade, Thematic Session on Good Regulatory Practice (G/TBT/GEN/191, 17 March 2016), available at https://www.wto.org/english/ tratop_e/tbt_e/tbt_e.htm.

99 European Commission, Regulatory Cooperation in TTIP: The Benefits, supra note 95, at 4-5.

100 European Commission, Regulatory Cooperation in TTIP: The Benefits, supra note 95, at 3; European Commission, TTIP and Regulation: An Overview 9 (Feb. 10, 2015), available at http://trade.ec.europa.eu/doclib/docs/2015/february/tradoc_153121.pdf.

101 European Commission, Regulatory Cooperation in TTIP: The Benefits, supra note 95, at 6; European Commission, Good Regulatory Practices (GRPS) in TTIP, supra note 97, at 6 .

102 Statement by EU Chief Negotiator for TTIP, 29 April 2016, supra note 2, at 1; European Commission, TTIP Advisory Group, supra note 78, at 4.

103 European Commission, TTIP and Regulation, supra note 100, at 10-11. 
conformity assessment procedures and standards in the European Union and the United States are major obstacles in transatlantic trade. Accordingly, the European Union seeks to eliminate or reduce duplicative or overly burdensome conformity assessment procedures, ease the use of international standards in transatlantic trade, increase cooperation between standard-setting bodies in the European Union and the United States when developing new standards, and ensure easy access to information on technical regulations and standards applied in both the European Union and the United States. ${ }^{104}$ These issues continue to dominate the negotiations in this particular area. ${ }^{105}$

As regards SPS measures, the verification, certification and approval procedures applied in the United States are deemed rather stringent by the European Union. The European Union would like to improve the speed, predictability and transparency of those procedures, by establishing a single approval procedure for all EU exports, and ensuring that the equivalence of EU and U.S. testing procedures and inspections is recognised. ${ }^{106}$ Also, regulatory cooperation on SPS measures should play a key role. The European Union strongly insists that the SPS chapter of TTIP will not result in a lowering of EU food safety rules or a modification of the authorisation process for the growing and selling of genetically modified plants required under EU rules.$^{107}$ Moreover, the European Union affirms that the SPS chapter should contain animal welfare provisions. ${ }^{108}$ Discussions on verification and certification procedures as well as the institutional aspects of the SPS chapter appear to be the least sensitive. ${ }^{109}$

\section{Sectoral Chapters}

The sector-specific section would comprise nine chapters on the following industries: (i) chemicals, (ii) cosmetics, (iii) engineering products, (iv) information and communication technologies, (v) medical devices, (vi) pesticides, (vii) pharmaceuticals, (viii) textiles, and (ix) vehicles. ${ }^{110}$ These chapters would include rules on regulatory cooperation and regulatory compatibility specifically addressing those issues that are relevant to the industries concerned. ${ }^{111}$

As in the case of the horizontal chapters, the sector-specific chapters are not an invention but form part of other free-trade agreements, for example those concluded by the European Union in the last couple of years. ${ }^{12}$ So far, there seems

104 European Commission, Inside TTIP, supra note 59, at 20; European Commission, TTIP - State of Play, supra note 63, at 5.

105 Commission, Report of the $13^{\text {th }}$ Round of Negotiations, supra note 64, at 8-9; European Commission, TTIP Advisory Group, supra note 78, at 4.

106 European Commission, Inside TTIP, supra note 59, at 21; European Commission, TTIP and Regulation, supra note 100, at 11-12.

107 European Commission, Inside TTIP, supra note 59, at 22.

108 European Commission, Report of the $13^{\text {th }}$ Round of Negotiations, supra note 64, at 9.

109 European Commission, TTIP Advisory Group, supra note 78, at 4.

110 European Commission, Inside TTIP, supra note 59, at 17; European Commission, TTIP and Regulation, supra note 100, at 12-17.

111 European Commission, Inside TTIP, supra note 59, at 22-34; European Commission, TTIP and Regulation, supra note 100, at 12-17.

112 These include CETA, see European Commission, CETA - Summary of the Final Negotiating Results 18 (February 2016), available at http://ec.europa.eu/trade/policy/ 
to be good progress in the negotiations regarding chemicals, medical devices, pharmaceuticals, textiles and vehicles, whereas less progress has been achieved in the other four sectors. ${ }^{13}$

\section{RULES}

As previously pointed out, the rules part of TTIP would encompass several matters, most notably investment protection and ISDS. The inclusion of "investment" in the name of the intended transatlantic agreement provides an indication of the importance of investment protection and ISDS for the transatlantic economic relationship. ${ }^{114}$ In this respect, it must be noted that "investment protection" forms part of "investment", rather than being a self-standing issue, in the most recent free-trade agreements of the European Union, namely CETA and the EU-Vietnam FTA. ${ }^{15}$ This might be the same for TTIP: according to the EU proposal, investment protection and ISDS would be a component of the chapter on investment which, in turn, would belong to the title on trade in services, investment and e-commerce. ${ }^{116}$ Nonetheless, in its information to the public on TTIP, the European Commission treats investment protection and ISDS as if it were a self-standing chapter of the rules part. ${ }^{117}$

Irrespective of the exact location of investment protection and ISDS within the TTIP architecture, the European Union suspended negotiations on this particular issue at the end of 2013 and launched a consultation process with its Member States

in-focus/ceta; EU-Singapore FTA, see European Commission, An Informal Overview over the Content of the EU-Singapore FTA 4-6 (20 Sept. 2013), available at http:// ec.europa.eu/trade/policy/countries-and-regions/countries/singapore; EU - Korea FTA, see European Commission, EU-South Korea Free Trade Agreement: A Quick Reading Guide 3-5 (Oct. 2010), available at http://ec.europa.eu/trade/policy/countries-andregions/countries/south-korea.

113 European Commission, TTIP Advisory Group, supra note 78, at 5. After the last negotiating round at the end of April 2016, the EU chief negotiator for TTIP noted in this respect: "A lot of technical work has been done, but quite substantial work is also still ahead of us", supra note 2 , at 2.

114 See Cecilia Malmström, Opening Remarks: Discussion on Investment in TTIP 2-3 Speech at the meeting of the International Trade Committee of the European Parliament, (Mar. 18, 2015), available at $\mathrm{http}: / /$ ec.europa.eu/trade/trade-policy-and-you/publications.

115 Sections D and F of CETA chapter 8 on investment contain rules on investment protection and the resolution of investment disputes between investors and states, respectively (the CETA text is available at http://ec.europa.eu/trade/policy/in-focus/ceta (last visited Jun. 20, 2016); as regards the EU-Vietnam FTA, sections two and three of chapter II on investment (which belongs to the title on trade in services, investment and e-commerce) set forth rules on investment protection and the resolution of investment disputes, respectively (the text of the EU-Vietnam FTA is available at http://trade.ec.europa.eu/ doclib/press/index.cfm?id=1437 (last visited Jun. 20, 2016).

116 See EU Proposal on Investment Protection and Resolution of Investment Disputes ( Nov. 12, 2015), available at http://trade.ec.europa.eu/doclib/press/index.cfm?id=1230\#rules [hereinafter EU Proposal]

117 See The Overview of the EU Positions and Texts in the TTIP Negotiations available at http://trade.ec.europa.eu/doclib/press/index.cfm?id=1230 (last visited Jun., 20, 2016). 
and their national parliaments, the European Parliament and the public. ${ }^{118}$ This decision was a result of growing unease within the European Union on the effect that arbitration proceedings, and ensuing awards, in investor-to-state disputes under bilateral investment treaties - and by extension under similar rules in TTIP - could have on the right to regulate, ${ }^{119}$ notwithstanding the fact that ISDS is a traditional feature of more than 1400 bilateral investment treaties that EU Member States have concluded in the past. ${ }^{120}$ The consultation process raised a number of questions as to how the current system of investment protection and ISDS could be reformed in order to address the concerns in this respect.

As a result of the consultation process, the Commission presented a draft proposal to the Council and the European Parliament which was published in September 2015. ${ }^{121}$ The proposal relates to both investment protection as well as ISDS. As regards investment protection, the proposal is moderately reformist, since the standards of protection set out in the proposal are mostly traditional ones. ${ }^{122}$ But these standards are more clearly defined than has been the case so far, account being taken of prior case law in this area; this is especially true for the standards of "fair and equitable treatment" as well as "expropriation." 123 What is truly new, however, is a provision that safeguards parties' right to regulate in the public interest and, as a corollary, the right to change the existing legal and regulatory framework, even if such a change negatively affects investors' expectations of profit. ${ }^{124}$ Also, the proposal envisages a provision that exempts EU rules on state aid from the standards of protection so that the latter do not constitute a hindrance to enforcing the EU rules on state aid. ${ }^{125} \mathrm{~A}$ quick comparison of the standards of protection, as set out in the EU proposal, with the standards of protection provided for in TPP chapter 9 on investment shows that they largely correspond to each other, notwithstanding certain differences.

The EU proposal is much more radical with respect to ISDS in that it completely abandons the present system of ad hoc arbitrations in favour of an Investment Court system; this drastic change must be seen against the Union's ultimate intention to improve the international investment dispute resolution system through the creation of a permanent multilateral International Investment Court. ${ }^{126}$ The European

118 European Commission, Inside TTIP, supra note 59, at 42; European Commission, TTIP - State of Play, supra note 63, at 6.

119 See Malmström, Discussion on Investment in TTIP, supra note 114, at 3-4.

120 European Commission, Inside TTIP, supra note 59, at 41; Malmström, Discussion on Investment in TTIP, supra note 114, at 1.

121 Press Release, European Commission, Commission Proposes a New Investment Court System for TTIP and Other EU Trade and Investment Negotiations (Sept. 16, 2015), available at $\mathrm{http}: / /$ trade.ec.europa.eu/doclib/press/index.cfm?id=1364.

122 See European Commission, Reading Guide Draft Text on Investment Protection and Investment Court System in the Transatlantic Trade and Investment Partnership (TTIP), available at http://trade.ec.europa.eu/doclib/press/index.cfm?id=1365 (last visited Jun. 20, 2016).

123 Id.

124 Id. See also, EU Proposal, supra note 116, ch. II, sec. 2, art. 2.2.

125 European Commission, Reading Guide, supra note 122; EU Proposal, supra note 116, ch. II, sec. 2, arts 2.3 and 2.4 .

126 European Commission, Reading Guide, supra note 122. See also Cecilia Malmström who stressed in her speech to the Atlantic Council in Washington D.C. that the EU's new investment court system "is a step towards the global reform we need, ultimately leading to a global court", supra note 1, at 5. 
Union proposes a two-tiered system, consisting of an "Investment Tribunal", as first instance, and an "Appeal Tribunal" with the authority to hear appeals. ${ }^{127}$ This system is similar to the two-tiered system of judicial protection at Union level or the equally two-tiered system of the WTO dispute settlement mechanism.

The Investment Tribunal would be composed of 15 judges, three of whom would be randomly assigned to a particular case. ${ }^{128}$ Importantly, the Investment Tribunal would not be empowered to order the repeal, cessation or modification of the treatment found to be in breach of an applicable standard of protection. ${ }^{129}$ Moreover, the disputing party's domestic law would not be part of the applicable law, and the Investment Tribunal would not have jurisdiction to determine the legality of a challenged measure under the disputing party's domestic law. ${ }^{130}$ Where the Investment Tribunal would have to ascertain the meaning of the disputing party's domestic law as a matter of fact, it would be bound to follow the prevailing interpretation made by the courts or authorities of that party. ${ }^{131}$ In addition, the meaning given to the relevant domestic law by the Investment Tribunal would not be binding upon the courts or authorities of the disputing party. ${ }^{132}$

The Appeal Tribunal would be composed of six judges, of whom three, assigned at random, would sit to hear an appeal. ${ }^{133}$ The grounds for appeal would be limited to: (i) errors of the Investment Tribunal in interpreting or applying the applicable law, (ii) manifest errors of the Investment Tribunal in appreciating the facts, including the appreciation of relevant domestic law, and (iii) those provided for in Article 52 of the ICSID Convention, in so far as they are not covered by the aforementioned two grounds of appeal. ${ }^{134}$ The judges of the Investment Tribunal and the Appeal Tribunal would have to comply with ethical rules as well as a code of conduct. ${ }^{135}$

Apart from the foregoing features, the EU proposal also seeks to introduce other reforms to the way investment dispute settlement proceedings are conducted, amongst others by proposing a ban on forum shopping, full transparency of investment dispute proceedings, early dismissal of unfounded claims, intervention by third parties and the "loser pays" principle. ${ }^{136}$ These proposed reforms are similar to new features found in TPP chapter 9 on investment.

Negotiations on investment protection and ISDS resumed in February 2016; during the twelfth round of negotiations, discussions focused on comparing the textual proposals of both sides with a view to identifying those areas that need further substantive discussions as well as those areas where there is convergence. ${ }^{137}$ Discussions then continued during the thirteenth and fourteenth

\footnotetext{
$I d$.

128 EU Proposal, supra note 116, ch. II, sec. 3, arts 9. 2, 9.6, 9.7.

29 Id. at ch. II, sec. 3, art. 28.1.

Id. at ch. II, sec. 3 , arts. $13.3,13.4$.

Id. at ch. II, sec. 3, art. 13.3.

$I d$. at ch. II, sec. 3 , art. 13.4 .

33 Id. at ch. II, sec. 3, arts. 10.2, 10.8 and 10.9 .

Id. at ch. II, sec. 3, art. 29.1.

135 Id. at ch. II, sec. 3, art. 11 and annex II.

136 European Commission, Reading Guide, supra note 122.

137 European Commission, Report of the Twelfth Round of Negotiations for the Transatlantic Trade and Investment Partnership (TTIP) 19 (Mar. 23,2016), available at http://ec.europa. $\mathrm{eu} /$ trade/policy/in-focus/ttip/documents-and-events/index_en.htm\#negotiation-rounds.
} 
rounds of negotiations, and some progress has been made towards consolidating text on standards of treatment. ${ }^{138}$ The United States asked detailed questions about the Investment Court system proposed by the European Union, especially the policy rationale behind the proposal and how the proposed system would function. ${ }^{139}$

An interesting - and by no means hypothetical - question is whether the Court of Justice of the European Union would consider the Investment Court System proposed by the European Union to be compatible with EU primary law. The Court of Justice has already been asked on several occasions ${ }^{140}$ to consider whether a system of judicial protection established under an international agreement to be concluded by the European Union, would be in conformity with the EU Treaties. The Court of Justice has ruled on this issue most recently in relation to the planned accession of the Union to the European Convention on Human Rights. In its opinion, the Court of Justice acknowledged that the Union's competence to conclude international agreements "necessarily entail[s] the power to submit to the decisions of a court which is created or designated by such agreements as regards the interpretation and application of their provisions." 141 However, the Court of Justice held that there must be "no adverse effect on the autonomy of the EU legal order." 142 and any decision by such a court "must not have the effect of binding the EU and its institutions, in the exercise of their internal powers, to a particular interpretation of the rules of EU law." 143 It would seem that these requirements are met as regards the investment dispute settlement system proposed by the European Union, since EU law would not constitute applicable law for purposes of investment dispute resolution proceedings, ${ }^{144}$ the Investment Tribunal would not have jurisdiction to determine the legality of a challenged measure under Union law, ${ }^{145}$ and the meaning given to Union law by that Tribunal would not be binding on the EU courts or authorities.

138 European Commission, Report of the $13^{\text {th }}$ Round of Negotiations, supra note 64, at 18; European Commission, Report of the $14^{\text {th }}$ Round of Negotiations for the Transatlantic Trade and Investment Partnership 14 (July 2016, available at http://ec.europa.eu/trade/ policy/in-focus/ttip/); European Commission, TTIP Advisory Group, supra note 78, at 5.

139 European Commission, Report of the $13^{\text {th }}$ Round of Negotiations, supra note 64, at 18.

140 See opinion 1/91, EUR-Lex 61991CV0001 (Dec. 14, 1991); opinion 1/09, EUR-Lex 62009CV0001 (Mar. 8, 2011); and opinion 2/13, EUR-Lex 62013CV0002 (Dec. 18, 2014).

141 Opinion 2/13, supra note 140, para. 182.

142 Id. at para. 183.

143 Id. at para. 184.

144 See also Christoph Herrmann, The Role of the Court of Justice of the European Union in the Emerging EU Investment Policy, 15 J. World Inv. \& Trade 570, 582-83 (2014).

145 But see Steffen Hindelang, Repellent Forces: The CJEU and Investor-State Dispute Settlement, 53 Archiv des VölKerRechts 68 (2015), who argues that "a tribunal's damages award [...] might de facto impact interpretations and review for legality of EU measures in the light of superior EU law by the CJEU", id. at 79-80. 


\section{Exclusive Competence of THE European Union for CONCLUding TTIP?}

The question whether TTIP would fall within the exclusive competence of the European Union, or whether the competence for concluding TTIP is shared between the European Union, on the one hand, and its Member States, on the other, is of highly practical relevance. If the latter was the case, then TTIP would have to be ratified by all Member States, which means that each and every EU Member State would have an effective veto power over TTIP's ratification. This is relevant because the mood in some Member States, for instance Belgium, France and Germany, is such that ratification by their national parliaments is all but ensured.

At first, the issue does not seem to be very difficult to determine. The common commercial policy falls within the exclusive competence of the Union. ${ }^{146}$ But this is not the end of the story. Two caveats apply. The first caveat arises with respect to transport, including transport services; the negotiation and conclusion of "international agreements in the field of transport" is not governed by Article 207 TFEU, the relevant provision on the common commercial policy, but is "subject to Title VI of Part Three", ${ }^{147}$ which is the title on transport. In that area, the competence is shared between the Union and the Member States. ${ }^{148}$ As regards a more or less identical provision to Article 207(5) TFEU, namely Article 133(6), third subparagraph, E.C. Treaty, the Court of Justice held that the latter provision "seeks to maintain, with regard to international trade in transport services, a fundamental parallelism between internal competence [...] and external competence [...], each competence remaining - as previously - anchored in the title of the Treaty specifically relating to the common transport policy." 149

However, the European Union also has exclusive competence for the conclusion of an international agreement when its conclusion is provided for in a legislative act of the Union, or is necessary to enable the Union to exercise its internal competence, or insofar as its conclusion may affect common rules or alter their scope. ${ }^{150}$ The last option in particular could be relevant as regards commitments on transport services under TTIP. But the Court of Justice has already held that any distortions in the flow of (transport) services in the internal market which might arise from international commitments on (transport) services do not in themselves affect the common Union rules on (transport) services and are thus not capable of establishing an (exclusive) external Union competence. ${ }^{151}$ The same rationale should apply to TTIP.

146 TFEU art. 3(1)(e).

${ }^{47}$ Id. art. 207(5).

${ }_{48} I d$. art. $4(2)(\mathrm{g})$.

49 Opinion 1/08, EUR-Lex 62008CV0001 (Nov. 30, 2009), para. 164.

150 TFEU art. 3(2). This provision is also applicable to areas where the competence is, in principle, shared between the Union and its Member States because of its overriding character, Christian Pitschas, Economic Partnership Agreements and EU Trade Policy: Objectives, Competences and Implementation, in EU Bilateral Trade Agreements and Intellectual Property: For Better or Worse? 209, 221 (Josef Drexl et al. eds., 2014).

151 Case C-476/98, Commission v. Germany, 2002 E.C.R. I-9855. para. 111 (referring to Opinion 1/94, EUR-Lex 61994CV0001 (Nov. 15, 1994), paras. 78 and 79). 
In addition, there is a second caveat which relates to the area of administrative cooperation, including the cooperation between Member States' regulatory authorities. In this area, the competence is not even shared between the European Union and its Member States. Rather, the European Union may only "carry out actions to support, coordinate or supplement the actions of Member States." 152 In particular, the European Union is not empowered to adopt measures in the area of administrative cooperation that would lead to a "harmonisation of the laws and regulations of the Member States." 153 This is relevant when it comes to the common commercial policy; although the Union's competence in this area is exclusive, it is explicitly restricted in that it "shall not lead to harmonisation of legislative or regulatory provisions of the Member States in so far as the Treaties exclude such harmonisation." ${ }^{154}$ Yet TTIP's horizontal chapter on regulatory cooperation and its sector-specific chapters would commit regulatory authorities to pursue a common approach to the process of designing and developing regulatory measures. One might counter that this commitment would not be subject to dispute settlement under TTIP, according to the EU proposal. But this objection would miss the point; the commitment retains a legal nature, nonetheless. Given that international agreements concluded by the European Union are binding on the EU institutions and EU Member States, ${ }^{155}$ TTIP would lead to a harmonization of the laws and regulations of Member States regarding the regulatory cooperation to be undertaken by their regulatory authorities. ${ }^{156}$ This would not be compatible with Article 207(6) TFEU read in conjunction with Article 197(2) TFEU.

In conclusion, it is argued that the European Union does not have an exclusive competence for TTIP. Consequently, TTIP would have to be ratified as a "mixed agreement" by both the European Union and its Member States. ${ }^{157}$ This may complicate the process, possibly to the point where the ratification of TTIP is seriously at risk of being rejected by some Member States.

\section{IMPACT OF TTIP}

TTIP would have a severe impact on the multilateral trading system, and this impact would be amplified further if TPP also entered into force. TTIP would certainly not mean that the European Union or the United States would abandon the multilateral trading system, but the latter would be relegated to second place, at least in practical terms. Similar to TPP, where accession is a possibility, albeit a

\footnotetext{
TFEU art. 6(g).

Id. at art. 197(2).

Id. at art. 207(6).

155 Id. at art. 216(2).

156 Christian Pitschas, Transatlantic Trade and Investment Partnership (TTIP) und Regulatorische Konvergenz in Die WTO Nach BaLI - Chancen und Risiken 141, 159 (Dirk Ehlers, Christian Pitschas \& Hans-Michael Wolffgang eds., 2015).

157 This was acknowledged by Karel De Gucht, The Transatlantic Trade and Investment Partnership: The Real Debate 5 (Speech/14/406, May 22, 2014), available at http:// ec.europa.eu/trade/trade-policy-and-you/publications.
} 
distant one for the moment, for countries that belong to the Trans-Pacific region, TTIP would be open for accession, ${ }^{158}$ which may be particularly relevant for Switzerland, ${ }^{159}$ thereby making its "plurilateralisation" through enlargement a possibility. ${ }^{160}$

The impact on developing countries would conceivably be even harsher. In contrast to other developed countries, such as Australia, Canada, New Zealand and South Korea, which intend to negotiate or have already negotiated free-trade agreements with the European Union that incorporate obligations similar to TPP or TTIP, developing countries are either not (yet) in a position or not (yet) willing to negotiate such far reaching agreements. The Economic Partnership Agreements concluded or negotiated by the European Union with several ACP regional groups are not a substitute in this respect. ${ }^{161}$ This is particularly true for LDCs; while their goods enjoy duty-free, quota-free access to the EU market and, albeit to a more limited extent, the U.S. market, it will prove exceedingly difficult for them to meet the technical regulations and standards that will shape the transatlantic market or engage in the kind of regulatory cooperation envisaged by the two parties. ${ }^{162}$ They are likely to be further marginalized as regards trade with the European Union and the United States.

\section{OUTLOOK}

At this juncture, it is uncertain whether the TTIP negotiations will be concluded by the end of this year. If not, it could mean that TTIP will never see the light of day; this may depend also on who will become the next U.S. President. But even if the TTIP negotiations will be concluded (one day), it is far from guaranteed that it will get the necessary approval from all Member States. This author takes the view that

158 The EU Proposal for Institutional, General and Final Provisions provides in article X.17 that TTIP "is open to accession by non-Parties possessing full autonomy in the conduct of their external commercial relations and of the other matters provided for in this Agreement as the Parties may agree", available at http://trade.ec.europa.eu/doclib/ press/index.cfm?id=1527 (last visited Sept. 29, 2016). The European Commission explained that "there should be a possibility for other countries to join and a geographical limitation on who could join was not deemed necessary", Transatlantic Trade \& Investment Partnership Advisory Group. Meeting Report, 23 June 2016, at 5, available at http://ec.europa.eu/trade/policy/in-focus/ttip/documents-and-events/index_en.htm\#_ documents.

159 Accord Transatlantique: Les négociations avancent lentement, ENTREPRISE Romande, 29 Jan. 2016, 8.

160 Malmström, The WTO after Nairobi, supra note 11, at 2 (“... our strong first preference will be for multilateral solutions ... However, we must also be realistic. If it's a choice between making progress with a smaller number of partners or no progress at all, then we will choose to move forward - plurilaterally.")

161 But see Cecilia Malmström, TTIP and Developing Countries 3 (Speech, Jun. 21, 2016), available at $\mathrm{http} / / / \mathrm{ec}$. europa.eu/trade/policy/in-focus/ttip/documents-and-events/index_ en.htm\# documents.

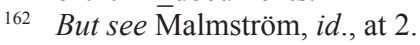


they, too, have to ratify TTIP; the issue of whether TTIP is a "mixed agreement" will almost certainly be referred to the Court of Justice for its - legally binding opinion. ${ }^{163}$

TTIP would be a watershed for the multilateral trading system, just as TPP. It risks undermining this system and its pre-eminent institution, the WTO, as the European Union and the United States would attempt to create "a more integrated transatlantic marketplace." 164 They would probably spend considerably less time on multilateral trade issues. This is all the more true if TPP enters into force. TPP parties, including the United States, would also try to build a more integrated transpacific marketplace. This would put the European Union under more pressure to conclude free-trade agreements with those TPP parties with whom it does not yet have such agreements, especially Australia and New Zealand, thereby even further distracting the European Union from the multilateral trading system.

To answer the question posed by the title of this article: TTIP is a golden opportunity to build a transatlantic marketplace, but this opportunity comes with a hefty price tag. Only the future will tell whether that price is worth paying.

163 Note that the European Commission has requested an opinion from the Court of Justice on whether the free-trade agreement with Singapore falls within the exclusive competence of the Union, see Press Release, European Commission to Request a Court of Justice Opinion on the Trade Deal with Singapore (Mar. 4, 2015), available at http:// trade.ec.europa.eu/doclib/press/index.cfm?id=1269.

164 HLWG, Final Report, supra note 22, at 3. 